удк 342.9

DOI https://doi.org/10.32837/pyuv.v0i1(30).536

\author{
M.C. Шум \\ orcid.org/0000-0002-4514-1131 \\ здобувач \\ Науково-дослідного інституту публічного права
}

\title{
ВИЗНАЧЕННЯ ШЛЯХІВ УДОСКОНАЛЕННЯ АДМІНІСТРАТИВНО-ПРАВОВОГО РЕГУЛЮВАННЯ ОРГАНІЗАЦІЇ ДІЯЛЬНОСТІ АПАРАТУ СУДУ
}

Постановка проблеми. Національне законодавство України постійно перебуває в стані динаміки, зазнаючи змін і доповнень. Законодавець такими змінами намагається адаптувати процес судочинства, процес організації діяльності судових органів до умов сучасності, реалізуючи процес реформування судової влади. Це дослідження спрямоване на вивчення питання адміністративно-правового регулювання організації діяльності апарату суду. Актуальність дослідження цього питання зумовлена необхідністю проведення постійного моніторингу чинного законодавства у сфері забезпечення діяльності судів та судочинства загалом для проведення за необхідності його удосконалення.

Аналіз останніх досліджень і публікацій. Дослідженнями окремих питань, присвячених саме адміністративно-правовому регулюванню діяльності апарату суду, займалися такі вчені, як В.Б. Авер'янов, О.М. Бандурка, Ю.П. Битяк, С.Г. Братель, В.Д. Бринцев, Н.Л. Губерська, Є.В. Додін, Т.О. Коломоєць, Б.М. Лазарєв, Л.М. Москвич, Н.Р. Нижник, В.Г. Перепелюк, Л.Л. Попов, Н.Г. Саліщева, В.Д. Сорокін, Ю.О. Тихомиров, Ю.М. Фролов та інші.

Мета статті - на основі поглядів науковців аналізу чинного законодавства визначити напрями вдосконалення адміністративно-правового регулювання організації діяльності апарату суду.

Виклад основного матеріалу дослідження. На значимість цього питання для судової системи та процесу здійснення судочинства звертає увагу А. Стрижак, зазначаючи, що питання правового регулювання діяльності щодо організаційного забезпечення судів загальної юрисдикції перебуває в єдиній площині з вирішенням проблем підвищення загального рівня якості функціонування правосуддя в державі [1, с. 149].

Особливості функціонування судової системи в Україні зумовлюють необхідність вироблення комплексу правових засобів постійного впливу та упорядкування суспільних відносин, який був би здатний на належному рівні забезпечити організацію та діяльність судів без загрози порушення принципу недоторканності суддів та втручання у процес здійснення правосуддя [1, с. 149].

Отже, проаналізувавши погляди науковців на дефініцію адміністративно-правового регулювання, можемо визначити, що належне здійснення такого регулювання організації діяльності апарату суду забезпечить зростання ефективності функціонування судової системи та рівня довіри населення до судів та судових рішень.

У лютому 2019 р. Центром Разумкова було проведено дослідження на тему «Ставлення громадян України до судової системи». За його результатами, на загальнонаціональному рівні на питання «Як Ви вважаєте, чи є сьогодні в Україні судді незалежними?» $3 \%$ опитуваних відповіли «так», $19 \%$ опитуваних відповіли «загалом судді є незалежними, але можливий вплив на деяких представників суддівського корпусу», $33 \%$ опитуваних відповіли «судді є переважно залежними, але на деяких суддів вплинути неможливо», $35 \%$ опитуваних відповіли «судді є повністю залежними», а $11 \%$ опитуваних вибрали варіант «важко відповісти» [2, с. 29].

Вказані результати показують доволі низький рівень довіри населення країни до реалізації принципу незалежності суддів та підкорення їх тільки закону. Важлива роль у підвищенні рівня довіри відведена саме здійсненню адміністративно-правового регулювання питань організації діяльності судів та апаратів судів шляхом уникнення в законодавстві прогалин, неоднозначних трактувань його положень, невизначеності процедур, пов'язаних з організаційними заходами забезпечення функціонування судочинства.

Вказані показники є невтішними, отже, на законодавчому рівні має бути проведено адаптацію нормативно-правових актів у сфері правосуддя до вимог сучасностішляхомїх глибокого аналізу, внесеннязмін, зоглядунавсінеузгодженостіміжними.

На необхідність належного адміністративно-правового регулювання організаційних питань функціонування системи правосуддя звертає увагу M.I. Пипяк, зазначаючи, що від того, наскільки правильно й точно закріплені положення щодо діяльності судів, залежить їх практична реалізація, тоді як відсутність вичерпних для розуміння законодавчих приписів, навпаки, спричиняє різне їх трактування, внаслідок цього порушується процес ефективного функціонування судової системи [3, с. 100].

Провівши наукове дослідження щодо адміністративно-правових засад організації діяльності апарату суду, ми маємо змогу спробувати визна- 
чити прогалини, які має чинне законодавчі у сфеpi цих правовідносин. Наявність цих прогалин призводить до недосконалості функціонування судової системи загалом, судів та апаратів судів, що, своєю чергою, призводить до порушення прав та законних інтересів особи, яка звертається до суду, розраховуючи на справедливе судочинство та законне і обгрунтоване рішення по справі.

Вивчаючи напрями вдосконалення адміністративно-правового регулювання організації діяльності апарату суду, вважаємо за необхідне звернутись до Стратегії реформування судоустрою, судочинства та суміжних правових інститутів на 2015-2020 роки, схваленої Указом Президента України від 20.05.2015 р. № 276/2015 (далі Стратегія) [4].

У Стратегії визначено, що нині система правосуддя не виконує поставлених перед нею завдань на належному рівні. У сфері діяльності апарату суду можна виділити такі чинники: недосконалість кадрового планування в системі судової влади; недосконалість методик визначення оптимального кількісного складу суддів і чисельності працівників апаратів судів відповідно до навантаження; непропорційне робоче навантаження на суддів і працівників апарату судів і відсутність механізмів оперативного вирівнювання навантаження на суддів; відсутність чи недостатній рівень використання можливостей сучасних інформаційних систем; низький рівень публічності сфери правосудця та довіри до судової системи взагалі й до суддів зокрема тощо [4].

Отже, враховуючи зазначене вище, можна дійти висновку, що чинне законодавство України у сфері адміністративно-правового регулювання діяльності апаратів судів щодо організації їх діяльності перебуває в недосконалому стані, вимагає негайного доопрацювання, систематизації та оновлення.

Отже, вважаємо за доцільне в нашому дослідженні детально зупинитися на деяких недоліках чинного законодавства, що регулює організаційно-забезпечувальну діяльність апарату суду, які вважаємо основними.

Насамперед варто звернути увагу на недостатність законодавчого визначення та врегулювання питання правового статусу апарату суду, який відповідно до норм ч. 1 ст. 155 «Апарат суду» Закону України «Про судоустрій та статус суддів» від 02.06.2016 р. № 1402-VIII покликаний здійснювати організаційне забезпечення роботи суду та очолюється керівником апарату [5]. Тобто на рівні спеціального закону відсутне визначення апарату суду як його складової частини, поняття апарату суду та не розкрите коло його функцій. Аналогічна проблема стосується і апарату Верховного Суду. Ч. 1 ст. 156 «Особливості апарату Верховного Суду» Закону України «Про судоустрій та статус суддів» від 02.06.2016 р. № 1402-VIII визначає, що організаційне забезпечення діяльності Верховного Суду здійснюється апаратом Верховного Суду [5].

Норми згаданих статей не характеризують адміністративно-правовий статус апарату суду, не визначають коло його прав та обов'язків, не визначають функції, які він має реалізовувати, що, відповідно, призводить до складностей його розуміння, визначення та практичного застосування цих норм закону.

Проблематика недостатнього законодавчого врегулювання стосується і статусу працівників апарату суду. По-перше, відсутній перелік посад, які входять до складу апарату суду, по-друге, відсутнє понятійне визначення цих посад, по-третє, не врегульовано кваліфікаційні вимоги до претендентів на ці посади та порядок їх обрання та призначення, по-четверте, відсутнє визначення умов притягнення їх до відповідальності як державних службовців.

Проаналізувавши Закон України «Про судоустрій i статус суддів» від 02.06.2016 p. № 1402-VIII, можемо дійти висновку, що правовий статус працівників апарату суду ним не розкривається і специфіка не визначається, лише ч. 6 ст. 155 "Апарат суду» визначає, що правовий статус працівників апарату суду визначається Законом України «Про державну службу» з урахуванням особливостей, визначених цим Законом [5].

Закон України «Про судоустрій і статус суддів» від 02.06.2016 р. № 1402-VIII [5] нормативно визначає існування у складі суду таких посад, як помічник судді, секретар судового засідання, науковий консультант та судовий розпорядник. При цьому вказаний закон не зараховуе помічника судді до структури апарату суду та не визначає той факт, що помічник судді несе патронатну службу. Так, ст. 157 «Помічники суддів» Закону України «Про судоустрій і статус суддів» від 02.06.2016 р. № 1402-VIII [5] визначає, що кожен суддя має помічника (помічників), статус і умови діяльності якого (яких) визначаються цим Законом та Положенням про помічника судді, затвердженим Радою суддів України, при цьому судді самостійно здійснюють добір своїх помічників, які призначаються та звільняються керівником апарату суду, за поданням судді. Що стосується професійної діяльності помічника судді, то він підзвітний лише відповідному судді, тобто управлінські функції керівника апарату суду на помічника судді не поширюються [5].

O.М. Радченко наголошує, що посада помічника судді в судах загальної юрисдикції є, поза сумнівом, надзвичайно важливою, оскільки дає змогу якісніше й ефективніше забезпечувати роботу суддів, а отже, і якість судочинства в Україні. Незважаючи на це, його правовому статусу та місцю 
в судовій системі, на нашу думку, не приділено належної уваги [6, с. 11].

Стосовно секретарів судового засідання та наукових консультантів, Закон України «Про судоустрій і статус суддів» від 02.06.2016 p. № 1402-VIII [5] взагалі не містить окремої статті, де б визначався правовий статус цих працівників апарату. Згаданий Закон лише зазначає, що до штату апарату судів входять також секретарі судового засідання, наукові консультанти [5].

Секретар судового засідання виступає ключовою процесуальною фігурою в плані організаційного забезпечення здійснення судочинства, оскільки норми всіх процесуальних кодексів передбачають обов'язкову участь секретаря судового засідання в судовому процесі.

В.Б. Пчелін, аналізуючи правові засади діяльності секретаря судового засідання в адміністративному судочинстві України, дійшов висновку, що виконувані секретарем функції повною мірою підпадають під критерії функцій з обслуговування. А тому можна зазначити, що правовий статус секретаря судового засідання, так само як й інших працівників апарату суду (окрім керівника), не може бути визначено на рівні Закону України «Про державну службу». На думку автора, вищенаведена ситуація є законодавчою помилкою [7, с. 145].

Ст. 159 «Служба судових розпорядників» Закону України «Про судоустрій і статус суддів» від 02.06.2016 p. № 1402-VIII [5], знову ж таки, не визначає цю службу як складник апарату суду, регламентуючи, що судові розпорядники призначаються на посаду і звільняються 3 посади керівником апарату відповідного суду, але при цьому визначає, що судові розпорядники керуються у своїй діяльності цим Законом, вимогами процесуального закону, відповідними правилами та інструкціями, розпорядженнями голови суду та судді, не згадуючи при цьому про підпорядкування їх керівнику апарату суду.

Враховуючи зазначене вище, можемо дійти висновку, що норми Закону України «Про судоустрій і статус суддів" від 02.06.2016 р. № 1402-VIII [5], якими регулюється адміністративно-правовий статус апарату суду та його працівників, є недосконалими, потребують негайного доопрацювання для усунення неточностей та неоднозначності в його розумінні та визначені.

Таким чином, пропонуємо ч. 1 ст. 155 «Апарат суду» Закону України «Про судоустрій і статус суддів» від 02.06.2016 p. № 1402-VIII [5] викласти в такій редакції:

«Апарат суду - це посадові особи суду, які здійснюють свою діяльність згідно із Законом України «Про державну службу» та цим Законом, спільно з іншими уповноваженими суб'єктами публічної адміністрації покликані забезпечити реалізацію права учасників суспільних відносин на вільний доступ до правосуддя, справедливе та об'єктивне судочинство, шляхом належного організаційного забезпечення суддям необхідних умов для відправлення правосуддя. Апарат суду очолює його керівник».

Ч. 1 ст. 156 «Особливості апарату Верховного Суду» Закону України «Про судоустрій і статус суддів» від 02.06.2016 p. № 1402-VIII [5] викласти в такій редакції:

«Організаційне забезпечення діяльності Верховного Суду здійснюється апаратом Верховного Суду, статус якого визначається з урахуванням ч. 1 ст. 155 цього Закону».

Питання визначення правового статусу працівників апарату суду мають бути врегульовані та розкриті саме нормами Закону України «Про судоустрій і статус суддів» від 02.06.2016 р. № 1402VIII [5], визначаючи поняття та перелік елементів адміністративно правового статусу працівників апарату суду.

Таким чином, пропонуємо ч. 6 ст. 155 «Апарат суду» Закону України «Про судоустрій і статус суддів» від 02.06.2016 р. № 1402-VIII [5] викласти в такій редакції:

«Адміністративно-правовий статус працівників апарату суду - це правове становище посадової особи в системі судочинства, що покликана здійснити організаційне забезпечення діяльності судів, зумовлене особливим порядком зайняття посади, іï компетенцією, колом прав та обов'язків у сфеpi правосуддя та особливістю відповідальності як державного службовця. Правовий статус працівників апарату суду визначається цим Законом з урахуванням особливостей, визначених Законом України «Про державну службу».

Також, на нашу думку, для повноцінного розкриття та врегулювання адміністративно-правового статусу апарату суду та його працівників на рівні Закону України «Про судоустрій і статус суддів» від 02.06.2016 р. № 1402-VIII [5] має бути визначено перелік кваліфікаційних вимог до претендентів на посади в апараті суду.

Таким чином, пропонуємо ст. 155 «Апарат суду» Закону України «Про судоустрій і статус суддів» від 02.06.2016 р. № 1402-VIII [5] доповнити ч. $4^{1}$ та ч. $5^{1}$, і викласти їх в такій редакції:

« $4^{1}$ Особа, яка претендує на обійняття посади керівника апарату суду, його заступника (заступників), має відповідати загальним вимогам, визначеним Типовим положенням про апарат суду, що затверджено Наказом Державної судової адміністрації України.

Спеціальні вимоги до осіб, які претендують на обійняття посад керівника апарату місцевого суду та його заступника, визначаються начальником відповідного територіального управління Державної судової адміністрації України, на обійняття посад керівника апарату апеляційного суду 
та його заступника - Головою Державної судової адміністрації України, на підставі типових вимог, затверджених Державною судовою адміністрацією України.

Особи, які претендують на обійняття посад керівника апарату вищого спеціалізованого суду та їх заступників, мають відповідати типовим вимогам (включаючи спеціальні), затвердженим Вищою радою правосуддя за поданням Комісії з питань вищого корпусу державної служби в системі правосуддя».

« $5^{1}$ На посади апарату суду призначаються особи, які відповідають вимогам щодо рівня освіти, професійного спрямування, освітньо-квалірікаційного рівня та стажу роботи, що визначені посадовими інструкціями відповідного суду по конкретній посаді».

Отже, підсумовуючи результати проведеного дослідження щодо удосконалення адміністративно-правового регулювання організації діяльності апарату суду, пропонуємо виділити основні недоліки чинного законодавства, що регулює організаційну діяльність апарату суду:

1) на законодавчому рівні недостатньо визначено та врегульовано питання правового статусу апарату суду, що ускладнює визначення складових елементів його правового статусу;

2) законодавчо практично не розкривається правовий статус працівників апарату суду, він врегульований переважно на рівні підзаконних актів і, знову ж таки, не в повному обсязі;

3) потребує законодавчого врегулювання ситуація з подвійним підпорядкуванням деяких категорій працівників апарату суду голові суду, судді та керівнику апарату суду;

4) чинне законодавство не визначає кваліфікаційні вимоги до претендентів на посади в апараті суду;

5) не врегульовано статус помічника судді, умови його прийняття на роботу та звільнення не узгоджуються 3 нормами законодавства в галузі праці;

6) норми законодавства у сфері судоустрою взагалі не визначають статус секретаря судового засідання і його складові елементи;

7) недосконало регламентується питання підпорядкування судових розпорядників керівнику апарату суду, що ускладнює процедуру управлінсько-організаційних відносин між ними;

8) потребує перегляду процедура погодження та затвердження штатного розпису та чисельності апарату суду;

9) потребують узгодженості норм Законів України «Про судоустрій і статус суддів» від 02.06.2016 p. № 1402-VIII та «Про державну службу» від 10.12.2015 р. № 889-VIII, з питань проведення конкурсів для призначення на посади державних службовців у судах;
10) не адаптовано норми законодавства щодо визначення категорій державних службовців, які обіймають посади державної служби в судових органах.

\section{Jimepamypa}

1. Стрижак А.А. Державне управління забезпеченням діяльності судів загальної юрисдикції : дис. ... канд. юрид. наук : 12.00 .07 ; Ін-т законодавства ВР України. Київ, 2005. 183 с.

2. Разумков центр. Ставлення громадян України до судової системи (звіт за результатами дослідження). URL: http://razumkov.org.ua/uploads/socio/ Infographics_2019_02.pdf.

3. Пипяк М.I. Ӓдміністративний суд у системі органів державної влади : дис. ... канд. юрид. наук : 12.00.07. Львів, 2016. 191 с.

4. Про Стратегію реформування судоустрою, судочинства та суміжних правових інститутів на 20152020 роки : Указ Президента України від 20.05.2015 p. № 276/2015. URL: https://zakon.rada.gov.ua/laws/ show/276/2015.

5. Про судоустрій і статус суддів : Закон України від 02.06 .2016 p. № 1402-VIII. URL: https://zakon.rada.gov.ua/laws/show/1402-19/page.

6. Радченко О.М. Помічник судді суду загальної юрисдикції: шляхи удосконалення правового статусу. Судова апеляиія. 2014. № 3. С. 11-16. URL: http://www.apcourtkiev.gov.ua/wp-content/uploads/ 2015/06/Radchenko.pdf.

7. Пчелін В.Б. Правові засади діяльності секретаря судового засідання в адміністративному судочинстві України. Юридичний науковий електронний журнал. 2016. № 4. C. 143-146.

8. Про державну службу : Закон України від 10.12.2015p. №889-VIII.URL:https://zakon.rada.gov.ua/ laws/show/889-19.

\section{Анотація}

Шул М. С. Визначення шляхів удосконалення адміністративно-правового регулювання організації діяльності апарату суду. - Стаття.

У статті проаналізовано проблемні аспекти в адміністративно-правовому регулюванні організації діяльності апарату суду. Визначено авторське бачення пропозицій у частині удосконалення понятійного апарату та внесення змін до законодавства в досліджуваній сфері. Визначено перелік кваліфікаційних вимог до претендентів на посади в апараті суду, які запропоновано чітко прописати в Законі України «Про судоустрій і статус суддів». Зроблено висновок, що основними недоліками чинного законодавства, що регулює організаційну діяльність апарату суду, є такі: 1) на законодавчому рівні недостатньо визначено та врегульовано питання правового статусу апарату суду, що ускладнює визначення складових елементів його правового статусу; 2) законодавчо практично не розкривається правовий статус працівників апарату суду, він врегульований переважно на рівні підзаконних актів $\dot{i}$, знову ж таки, не в повному обсязі; 3) потребуе законодавчого врегулювання ситуація 3 подвійним підпорядкуванням деяких категорій працівників апарату суду голові суду, судді та керівнику апарату суду; 4) чинне законодавство не визначає кваліфікаційні вимоги до претендентів на посади в апараті суду; 5) не врегульовано статус помічника судді, умови його прийняття на роботу та звільнення не узгоджуються з нормами законодавства в галузі праці; 6) норми законодавства 
у сфері судоустрою взагалі не визначають статус секретаря судового засідання і його складові елементи; 7) недосконало регламентується питання підпорядкування судових розпорядників керівнику апарату суду, що ускладнює процедуру управлінсько-організаційних відносин між ними; 8) потребує перегляду процедура погодження та затвердження штатного розпису та чисельності апарату суду; 9) потребують узгодженості норми законів України «Про судоустрій і статус суддів» від 02.06.2016 р. № 1402-VIII та «Про державну службу» від 10.12.2015 р. № 889-VIII з питань проведення конкурсів для призначення на посади державних службовців у судах; 10) не адаптовано норми законодавства щодо визначення категорій державних службовців, які займають посади державної служби в судових органах.

Ключові слова: судоустрій, судді, суд, апарат суду, статус, правовий статус, законодавства, кваліфікація, державний службовець.

\section{Summary}

Shum M. S. Determining ways to improve the administrative and legal regulation of the organization of the court staff. - Article.

The article analyzes the problematic aspects in the administrative and legal regulation of the organization of the court apparatus. The author's vision of the proposals in terms of improving the conceptual apparatus and introducing amendments to the legislation in the studied area is determined. The list of qualification requirements for applicants for positions in the court apparatus is defined, it is proposed to clearly state them in the Law of Ukraine "On the Judicial System and the Status of Judges". It is concluded that the main shortcomings of the current leg- islation governing the organizational activity of the court apparatus are: 1) the legal status of the court apparatus is insufficiently defined and regulated at the legislative level, which complicates the determination of the constituent elements of its legal status; 2) the legal status of the employees of the court apparatus is not legally disclosed, it is regulated mainly at the level of by-laws, and again, not in full; 3) the situation with the double subordination of certain categories of employees of the court apparatus to the head of the court, the judge and the head of the court apparatus is required for legislative regulation; 4) the current legislation does not specify the qualification requirements for applicants for positions in the court apparatus; 5) the status of assistant judge is not regulated, the conditions of his employment and dismissal are not consistent with the rules of the legislation in the field of labor; 6 ) the rules of the law in the field of judicial system do not determine at all the status of the court secretary and its constituent elements; 7) the issue of subordination of court administrators to the head of the court apparatus is not properly regulated, which complicates the procedure of administrative and organizational relations between them; 8) requires reviewing the procedure for approval and approval of the staffing list and the number of court staff; 9) require consistency of the Laws of Ukraine "On Judicial System and Status of Judges" of 14.06.2016 No. 1402-VIII and "On Civil Service" of 10.12.2015 No. 889-VIII, on the issues of competitions for appointment to civil servants in courts; 10) the norms of the legislation regarding the definition of categories of civil servants holding public service positions in the judiciary have not been adapted.

Key words: judicial system, judges, court, court apparatus, status, legal status, legislation, qualification, civil servant. 